\title{
PROHÁSZKA OTTOKÁR
}

\author{
PÁPAI LAJOS
}

Sík Sándor így összegezte Prohászka Ottokár hatását: „Prohászka legnagyobb, egyetemes jelentősége az a nagyszerü szintézis, amellyel harmonikus egységbe fogta az egész tradicionális kereszténységet és a huszadik század egész eleven kultúráját, amellyel kielégítő feleletet adott a korabeli ember legégetőbb problémáira."1

Mivel az elmúlt korszakok - és nem csak a kommunizmus 40 éve - elég egyoldalúan kezelték a magyar zseniket, nekünk mindent meg kell tennünk azért, hogy ne merülhessenek feledésbe, vagy hogy ne ferde beállítás legyen uralkodó velük kapcsolatban.

Prohászka mindenek előtt apostol volt, „Prohászkában az evangéliumi ember jelent meg, aki életével és tanításával bizonyságot akar tenni arról, hogy a modern világban nemcsak lehet, hanem kell is élni az evangéliumot”. ${ }^{2}$

De az apostol személyében csodálatos egységbe olvadt a tudós, jövőbe látó, lényeget észrevevő gondolkodó, az író és költő, a szociális reformer, a misztikus, a szent.

Ma Prohászkáról elsősorban mint teológusról, katolikus gondolkodóról szeretnék szólni, aki körülbelül 50 évvel előzte meg korát, és több gondolata a II. vatikáni zsinaton nyert megerősítést. Ugyanakkor röviden szeretnék majd szólni egy-két más kérdésről is vele kapcsolatban.

A századforduló táján nagy krízis alakult ki a katolikus egyházon belül, ezt nevezzük modernizmusnak, ami nagyon összetett probléma, tulajdonképpen szoros és történelmi értelemben a gondolkodás krízisét jelentette a katolicizmuson belül a 19. század végén, a 20. század elején..$^{*}$ Nem volt ez egységes rendszer, legfeljebb az elítélése által lett egységessé, amikor 1907-ben a Lamentabili sane exitu kezdetü dekrétummal és ugyancsak 1907-ben a Pascendi dominici gregis kezdetű enciklikával X. Pius elítélte. Mégis bizonyos közös vonásokat lehetett találni a modernista

\footnotetext{
${ }^{1}$ Gergely Jenő: Prohászka Ottokár - A „napbaöltözött ember”, Budapest, Gondolat, 1994, 7.

${ }^{2}$ Uo. 9 .

${ }^{3}$ * A modernizmussal kapcsolatban föleg Szabó Ferenc tanulmányait használtam fel. (P. L.)
} 
szerzőknél. Végül is ez egy törekvés volt arra, hogy kiszabaduljanak abból a teológiából, amelyet úgy írnak most le, hogy „szklerózisos” teológia, s amely a skolasztikus fogalmakat ismételgette, miközben a történelem, a természettudomány, a bibliatudomány fejlődött, ám mintha ezt nem is vették volna észre e teológia hívei, csak ismételgették tovább a skolasztikus gondolatokat.

Törekvés volt ez továbbá arra, hogy újrafogalmazzák a hitet, amelyet a modern ember számára is elfogadhatóan kívántak megfogalmazni, és hogy igazolják a kereszténység alapjait, de most már egy történetkritikai háttérben és azzal összefüggésben. A modernizmus tehát kísérlet, egyházon belüli kísérlet volt arra, hogy az exegézisbe, a történelembe, a teológiába valami újat hozzanak, azonban, ha szabad így mondani, mindez egy olyan gondolkodási mederben jött létre, amely gyanakvóvá vált minden dogmatizmussal szemben, és támogatta a szövegmagyarázatokat és az új módszereiket, arra törekedett, hogy feltöltse az egyházi tudomány, tudományosság hiánygödreit. Németországban egyébként a 19. század végén az egyetemeken egész sor katolikus, liberális irányzat létezett, és létrejött egy katolikus reformgondolat is, de azért nem lehet mondani, hogy ez valamiféle kapcsolatban volt a szigorúan értelmezett modernizmussal.

Angliában a modernizmussal kapcsolatosan Tyrrellt kell megemlíteni, aki 1909-ben halt meg. Itáliában a modernizmus főleg a szociális akció és a valláskultúra területén jelent meg R. Murrival, valamint S. Minocchivel és E. Buonaiutival. Ez utóbbival a későbbi XXIII. János pápa is kapcsolatban volt, és amikor pápa lett, előkereste a róla szóló följegyzéseket és följelentéseket, és odaírta melléjük tintával, hogy „Soha életemben nem voltam modernista. XXIII. János.” A modernizmus igazában akkor robbant, amikor 1902-ben, Párizsban megjelent Alfred Loisynak a híres piros kis könyve, a L'Évangile et l'Église, tehát $A z$ evangélium és $a z$ egyház, amely valójában egy történelmi apológia volt. De nem a római szisztémának, tehát a hagyományos skolasztikus teológiának, hanem a „felvilágosult katolicizmusnak" az apológiája, amely tulajdonképpen nem volt más, mint Adolf Harnack egyik könyvére való válasz. Harnack e könyve, a Das Wesen des Chistentums valójában a liberális protestantizmus történelmi apológiája volt. Loisynak a művét - s még inkább a hozzáfüzött magyarázatait, amelyek az Autour d’un petit livre címü munkájában jelentek meg 1903-ban - úgy ítélték meg, mint ami veszélyes a hitre. Publikációinak a száma, az érdeklődés, amelyet kiváltott, valamint az exegézis és a teológia területén megfogalmazott állásfoglalásai miatt őt tekintették a „par excellence” modernistának.

Természetesen nem soroljuk a modernisták közé azokat, akik bár újítók voltak, de megőrizték a távolságot a modernizmus tanbeli irányaival szemben. Ilyen például Maurice Blondel, aki a katolikus apologetikának az egyik megújítója volt, Laberthonnière vagy J. M. Lagrange OP, a neves biblikus. Nem szabad a modernizmust illetően elhamarkodottan szellemi szülőséget tulajdonítani Kantnak, Schle- 
iermachernak, Renannak vagy Newmannak. Loisy tézisei föleg a fundamentális teológiát érintették, mivel a modernista vállalkozásnak a központjában mindig a kinyilatkoztatás teológiája és annak az egyházban való a fejlődése volt. Loisy a „Nagy Kinyilatkoztató” címet adta Krisztusnak. Egyébként, hogyha valaki figyelmesen olvassa Hans Küngnek a Christ sein címü könyvét, akkor ott is valami hasonlót talál. Nem is annyira a személye, személye misztériuma miatt adta neki a „Nagy Kinyilatkoztató” címet, hanem mert szerinte Krisztus az, aki a legvilágosabban és legérthetőbben fogta fel a kapcsolatot Isten és ember között. Ez a percepció, ez a felfogás a központjában van tanításának, mivel Krisztus szerepe az, mondja ő, hogy leleplezze azt, ami minden ember lelke mélyén létezik, hogy jobban megértesse önmagában azt, amit Loisy úgy nevezett, hogy „révélation primitive”, tehát egy elsődleges kinyilatkoztatás, egy „révélation inexpliquée”, tehát még nem magyarázott kinyilatkoztatás, amelyet az ember hordoz, amely szintén bele van írva az ösztöneibe, a vallásos öntudat mélyére, és ezt kell aztán kibontani.

Szerinte tehát személyében, életében, tanításában Jézus nyilvánvalóvá tette azt, amit az ember úgy homályosan mindig megértett. Idézek tőle: „Isten kinyilatkoztatja magát az embernek az emberben, és az emberiség belép Istennel egy isteni közösségbe." ${ }^{4}$ G. Tyrrell, az angol modernista szerző szintén a kinyilatkoztatás témájával foglalkozott, és azt mondta, hogy a kinyilatkoztatásban nincs igazságközlés, mivel ez egy aktusa Istennek, akivel a hívő misztikus kapcsolatba lép. Tehát egy bizonyos meg nem fogalmazott, nem fogalmi kapcsolat jön létre az Isten és a hívő között, és aztán ezt később valamiféle prófétai ismeretben kifejtik azok, akik erre hivatottak, s ennek elemeit a korából meríti a próféta, aki befogadja a kinyilatkoztatást. Nyilván, hogyha a mai modern biblikumot tanulmányozza valaki, akkor látja, hogy mennyi megoldatlan probléma merült fel akkoriban, amelyekre próbálták keresni a választ, és nagyon sok zseniális meglátás is volt benne, még ha egy bizonyos ponton szélsőségek is megjelentek. A vallásos tapasztalat minden kinyilatkoztatás szíve, ajándék, amelyet Isten minden embernek megadhat. De a „típus-tapasztalat”, mondja Tyrrell, amely normaszerepet tölt be a hívőknél, az Jézus tapasztalata, és a vele közvetlen kapcsolatban álló apostoloké. Szerinte a hit kifejezéseinek nincs semmiféle realitásértékük. Tiszta szimbólumok, amelyeket a kor kulturális helyzete kondicionál, de mégis hasznosak számunkra, mert kiváltják bennünk a kinyilatkoztatás és a hit tapasztalatát.

Nos, amikor Prohászka hazajött Rómából, és itt kezdett tanítani, olvasni, írni, akkor ő is ismerte és használta Eduard Le Roy híres Dogme et critique című könyvét (1906), amelyben a szerző a dogmaértelmezésről gyüjtötte össze a vitairatait. Mikor $A z$ intellektualizmus túlhajtásai címü akadémiai székfoglaló disszertációját, aztán $A$ modern katolicizmus címü füzetét és egy karácsonyi cikkét írta, amely

${ }^{4}$ Dictionnaire de Théologie Fondamentale, Paris, Cerf, 1992, 268. 
„Több békességet” címmel jelent meg, ezt is használta. ${ }^{5}$ Szabó Ferenc jezsuita atya mondta, hogy könyvtárában megvolt Le Roynak a könyve, és Prohászka személyes jegyzetei is ott voltak a lapok szélén. ${ }^{6}$ Jó, hogy csak az ismeretelméleti résszel foglalkozott, mert még nagyobb baja is lehetett volna, ha a többit is kezdi ismertetni, hiszen így is ezt a három kis írását 1911-ben indexre tették. Ennek ellenére, bár modern volt, nem számít modernistának, és az írásaiban megtaláljuk azokat az alapvető pontokat, amelyekben Le Roy könyvének pozitív oldalait fölhasználja, a negatív oldalait pedig el tudja kerülni.

Nézzük meg most Prohászkának a véleményét egy-két olyan témában, amely később a zsinaton is elökerült!

A Soliloquiában írta 1919-ben: „Mi a lényeg az Egyházban? Az, ami a kereszténységben az égből jött, s mint isteni erő lépett a világba, szellem és lélek és élet volt, s történelmi csak akkor kezdett lenni, amikor emberi viszonyok közé lépve azokban elhelyezkedett. Sok alakja volt azon kezdve, mikor az Egyházat így jellemzi: »Credentium autem erat cor unum et anima una «, azaz: »a hívők sokaságának egy volt a szíve-lelke«. A »ius canonicum«, egyházi szervezet, tekintély megvolt lényegében, de a kapcsolatot a "cor unum et anima una" jellemezte a gyakorlatban. Sok-sok alakot öltött azóta is végig a történelmen, másokat keleten, másokat nyugaton és ugyancsak különbözőket a klasszikus középkori, újkori Egyházban. Ezeket a történeti formákat az államok, az uralkodó nézetek, a társadalmi fejlödés, a gazdasági élet határozták meg. Ezek jönnek, mennek, maguk is változnak, s változásukkal az egyházi formák reformját magukkal hozzák. Így lehet valami bizonyos időben egyházi s egyházias, ami előbb nem volt, az és megfordítva: lehetséges, hogy valami megszűnt egyháziasnak lenni, ami előbb az volt. Annak megítélése aztán, hogy mikor kell valamit, s hogyan behozni, hogy mi jó és korszerü, mi felel meg az igényeknek úgy, hogy a lelki életet fejleszti, nagy nézeteltérést, $s$ különféle állásfoglalást tür meg, és főleg két irányban osztja el a szellemeket: haladó és maradi irányban, aszerint, amint némelyek inkább a múltnak megszentelt hagyományait akarják fönntartani, még akkor is, ha azok nem szolgálják a lelki életet, és azokat ősi garnitúraképpen a szeszélyes idők forgandóságának feláldozni nem akarják; míg ellenben mások, nem kisebb szeretetből az Egyház iránt, de talán nagyobb megértésével az új idők igényeinek, az új formákat sürgetik. Ez utóbbiak szeretetének bátornak is kell lennie, mely nemcsak küzdeni kész a konzervatív elemek nehézkességével, de a rossz értelemben vett modernizmus vádját is nagylelküen el tudja viselni, s a gyanúsítást szívére nem veszi. Így volt ez mindig,

\footnotetext{
${ }^{5}$ Prohászka Ottokár: Élő kereszténység - Prohászka indexre került müvei, Budapest, Kairosz, 1998.

${ }^{6}$ Szabó Ferenc: „Keresztények a századfordulón”, Távlatok 2001, 346.

7 ApCsel 4,32.
} 
sokféle félreértés, ragaszkodás és féltés, hatalmi vágy, egyéni érzések, rokon- és ellenszenvek és szenvedélyek járnak az egyháztörténetben is. Miért is ne? Hiszen emberi története ez az isteni erőnek!"8

Prohászka nagyon lényeges dolognak tartotta azt, hogy az Egyház a maga tanításával beleálljon a kornak a kultúrájába, műveltségébe, tudományába. És akkor rengeteg érdekes dolgot lehet látni, amiken az ember meglepődik, ezeket milyen régen írta, és mennyire modernnek tünnek még ma is. Például a hit- és természettudománnyal kapcsolatban csak egy-két idézet. „Értsük tehát a helyzetet, és állítsuk bele a kereszténységet a kultúrvilágba, megfelelő belátást teremtve a régi igazságokba és érvényesítvén azokat a modern érzésben. Kössük össze a természetet a természetfölötti világgal, a szabadságot a tekintéllyel, földi célokat az örök céllal. Ne rögzítsük az örvényeket, hanem építsünk rajta hidakat. Ne hegyezzük ki az ellentéteket az Egyház s kultúra közt, s ne azonosítsuk a kultúra művét a hitetlenséggel, hanem tartsunk feléje, segítsük a profán kultúrában ki nem elégített lelkeket igaz, mély pünkösdi hitünk őserejével és melegével."9

Bár tudja, hogy lehetnek összeütközések, mégis kijelenti: „Teljesen keresztény alapon állni a hit és erkölcs dolgában, de a XX. század kultúrvilágában élni.” ${ }^{\circ}$ A Diadalmas világnézet címü könyvét pedig így kezdi: „Lehet-e a keresztény világnézetet beleállítani a mai kultúrvilágba? Ez az én problémám"11 (PRO DOMO, III.). „A kultúra sok új gondolatot vet föl, e gondolatokat le kell foglalnunk, s e világosság mellett egyre arra az égi fényre kell utalnunk, mely fény, s nem vívmány, s melyet nem lehet kimagyarázni sem természetrajzi evolúcióval, sem történeti fejlődésből. Így tettek a Gergelyek, Vazulok, Ágostonok az antik kultúrával, s így Szent Tamás az arab, zsidó világnézettel, s mit teszünk mi? Kövessük őket." ${ }^{12}$ Vagyis az új kultúrának a lehetőségeit megkeresztelni. Csak úgy érdekességként írtam ki egy-két dolgot, hogy miként nézte ő a századfordulón, például a fejlődéselmélet kérdését. Elkerülte a konkordizmust, vagyis a geológia, paleontológia napi állása és a bibliai teremtéstörténet egyeztetését, amely eleve téves út és megközelítés. A Galilei-ügy kapcsán II. János Pál pápa is idézte Baronius szavait: „A Szentlélek nem azt adta tudtunkra, hogy hogyan forog az ég, hanem, hogy hogyan jutunk az égbe." Vagyis a Biblia nem természettudományos ismereteket akar közölni, hanem a korabeli emberek világképét, kultúráját felhasználva, vallási, üdvösségünkre vonatkozó igazságokat. ${ }^{13}$

\footnotetext{
${ }^{8}$ Prohászka Ottokár: Naplójegyzetek III., Székesfehérvár, Agapé, 1977, 26-29.

${ }^{9}$ Prohászka Ottokár: Modern katolicizmus - Válogatás Prohászka müveiből, Budapest, Szent István Társulat, 1990, 135-136.

${ }^{10}$ Uo. 136.

${ }^{11}$ Prohászka Ottokár: A diadalmas világnézet, Székesfehérvár, Vörösmarty Nyomda, 1925.

${ }^{12}$ Uo. VII.

${ }^{13}$ Lásd Szabó: „Keresztények a századfordulón”, i. m. 337.
} 
A Föld és ég című kötetében azt írja: „A darvinistákkal szemben az igazi álláspont az, hogy hangoztassuk, hogy az ember nem állat, hogy van ember és állat között lényeges lénytani különbség, mely az emberben az értelem, az erkölcs, a vallás világát teremti meg. Ezen kívül ne állítsunk semmit. Ne mondjuk, hogy az anatómiai különbözőségek oly nagyok, hogy az evolúció elő nem teremthette az embernek testét. Hátha előteremtette? Hátha az emberi szervezet tényleg nem közvetlenül teremtetett az Istentől, hanem kifejlett az evolúció skáláján?! A mi tézisünk nem az, hogy az embernek van a majomtól lényegileg különböző szervezete, hanem hogy van lényegileg különböző természete.” ${ }^{14}$ „Az evolúciót illetően senkinek sem tanácsolom, hogy azt lehetetlennek tartsa; azt nem szabad állítani. Valamint sok a túlzás, $s$ az émelygős filozofálás az evolucionisták táborában: így lehet túlzás köztünk is; és ha ők sok bakot lőttek idétlen állításaikkal, nekünk magának a gondolatnak a visszavetését nem szabad ezekre a túlzásokra alapítanunk." ${ }^{15}$ „A szentírási elbeszélés a világ természettudományos fölértésében nem állja utunkat. A Szentírásnak ide vonatkozó részeit úgy fogjuk fel, hogy Isten kinyilatkoztatta Ádámnak önmagát és művét, a teremtést. Víziókban adta elő neki az Úr a teremtés történetét, oly alakban, amelyben azt az első ember s a nagy emberiség megérthette. $E$ víziók célja az embert az ő viszonyáról Istenhez, a világhoz kioktatni; céljuk nem tudomány, hanem vallás." ${ }^{16}$ Másik megjegyzése még, hogy: „A legnaivabb részlete a Szentírásnak az asszony teremtése. Szerencsétlen túlzásnak tartjuk némely teológusnak a kísérletezését, hogy a bordával való keletkezésnek, ha nem is szószerinti értelmét, de legalább azt a jelentését megmentsék, hogy az asszony tényleg a férfiból származott." ${ }^{17}$

Szabó Ferenc írja: „Prohászka helyesen látja, hogy Isten a világfejlődést a teremtő okság révén lendíti előre, és nem nyúl bele állandóan »kívülről« a fejlődés folyamatába. Ezt fejezi ki a szenttamási elv az első és másodlagos okokról, ezt fogalmazta meg tömören Teilhard de Chardin, akinek eszméihez oly közel állnak Prohászka meglátásai: „Dieu fait se faire les choses«. Isten cselekvővé teszi a dolgokat (és az embereket), nem pedig helyettük cselekszik." ${ }^{18}$ Aztán a Szentírás értelmezésével kapcsolatban: „Természettudományos tartalmat keresve a Genezisben, a Szentírás tekintélyének is ártottak, s a természettudósok ellenszenvét is magukra hárították. Viszont természettudósok is hozzászoktak a gyülölködéshez, és az

\footnotetext{
${ }^{14}$ Schütz Antal: Prohászka Ottokár Összegyüjtött munkái, IV., Budapest, Szent István Társulat, $1929,67$.

${ }^{15}$ Uo. 69.

${ }^{16}$ Uo. 75 .

${ }^{17}$ Uo. 76.

${ }^{18}$ Szabó: „Keresztények a századfordulón”, i. m. 337.
} 
Írás-értelmezőknek hibája miatt magát az Írást akarták hitelétől megfosztani. Ez is, az is betegség." ${ }^{19}$

Prohászka már 1907-ben ezt írta: „Lehetséges, hogy a Pentateuchusnak mostani formájában nem Mózes a szerkesztője, s sokkal későbbre, talán Sámuel idejébe, vagy még későbbi korba kell a compilációnak keltét tüznünk. Az Egyház tana a Szentírás sugalmazásáról érintetlen marad, jóllehet a nézet Mózes szerzőségéről elváltozik.” ${ }^{20}$ Aztán a kultúra területét nem szükítette le csak egyszerüen az Egyház és a teológia s természettudomány kapcsolatára, hanem számára ez kapcsolatban volt az életnek minden konkrét komoly kérdésével. Így például a szociális kérdéssel. 1916. április 25-én írja a naplójában: „Még azt sem jegyeztem föl, hogy elsütöttem a nagyágyút az OMGE gyűlésén és beadtam a földosztásról indítványomat. Röviden jeleztem s okoltam meg, hogy miért [...]. Máris megkezdődött a sajtóvélemények árama; a Világ is borzasztóan kifent, s kapok iratokat és telegramokat mindenfelől. Igazán nagy követ dobtam a »Velencei« magyar tóba, ebbe a széles sekély vízbe. Most kavarog, gyürüzik. Lehet mindenféle kifogást emelni e javaslat ellen; de azt el kell ismerni, hogy a népet magyar keresztény irányban kell földdel megtámogatni, no, és a latifundiumok igazán megértek a megosztásra már nálunk is." ${ }^{21}$

Aztán egy másik idézet, amikor a forradalom alatt, tehát a 19-es forradalmak alatt gondolkodik a változásokon, és azt mondja: „Ne akarjunk restituciót. Az sohase volt egészen, de szociális forradalmaknál teljesen lehetetlen. Ne vezessük tovább a rovatok kimutatását, hogy liberális vagy konzervatív, feudális vagy demokratikus. Még kevésbé fonjunk reakciós ostorokat a népnek a hátára [...], ezt káplársorban álló katonalelkek szeretik [...]. Kultúrát nem lehet teremteni plakátokkal [...], - Új világot sem azzal, hogy kifordítjuk a régit. [...] Nézzünk szét: Megbíznak-e azokban az elemekben, a vezetőkben, a politikai, gazdasági, kulturális törvényszéki új organizációban?" ${ }^{22}$ Itt arra hívja fel a figyelmet, hogy ilyen nagy változások idején nem szabad soha restitucióra gondolni. Aztán utána egy nagyon érdekes leírás van, amelyben leírja a 19-es első kommunizmussal kapcsolatban tapasztalatát az egész akkori társadalomról. Beszél itt a tisztikarról, beszél a népröl, beszél a kereszténységről, a papságról, szerzetesekről. Azt mondja, hogy: „A nép eszményi célokra nem kapható. A vallást pszichikai igénynek nézi, de csak a falusi templomtoronyról nyíló látóhatárban. A kultúra, a kereszténység hősies kitartásra $s$ vértanúságra nem számíthat nála. A blazírt és tyúkeszű intelligenciánál ez még inkább az eset. Annak szerepe a meghunyászkodás, s a kenyérkaraj melletti meg-

\footnotetext{
${ }^{19}$ Schütz: Prohászka Ottokár Összegyüjtött munkái, IV., i. m. 162.

${ }^{20}$ Prohászka: Modern katolicizmus, i. m. 149.

${ }^{21}$ Prohászka Ottokár: Naplójegyzetek I., Székesfehérvár, Agapé, 1991, 402.

${ }^{22}$ Prohászka Ottokár: Naplójegyzetek II., Székesfehérvár, Agapé, 1997, 223.
} 
vonulás. Panem... panem! Más probléma nincs. Az erkölcsi eszmény s a kenyér ütközésében az előbbi inponderabile lévén, quantité négligeable [elhanyagolható mennyiség]. No és a papság? Az általános beijedésben s bugyogó töltésben a szerzetesek vezettek; becsületes kivételt a zirciek, bencék, no meg az igazi rendek tettek, $\mathrm{s}$ aláírták a hittagadást. Nem vártam tőlük sokat, [...] Mindezek után pedig szemnyitogatás kell, látni kell. Vakok vagytok, kik vezettek? Kik lopták el meggyőzésünket, kik húzták ki gerincünket, oltották ki eszményünket, kik vetettek zizániát?" ${ }^{23}$ Ugyanakkor természetesen elöre is lát és az események mögött meglátja a történelem Urának cselekvését is. Amikor a tapasztalata az volt, hogy a saját házából kiűzték, ott a forradalmi vezetők berendezkedtek, végighányták a lépcsőházat, folyosót, Krisztus-szoborra rálőttek részegen, és így tovább, ő mégsem azt mondta, hogy itt a világ vége, hanem a következőt: „A nagy történelmet az Isten csinálja; hiszem, hogy kigöngyölíti az idők vásznát, s ráveti zseniális alkotással tervrajzait. Emberek az ő napszámosai; ott szerepelnek lelkükkel, szenvedélyeikkel; [...] Hát bizalom a világalakításba: jó erős kézben van; bizalom, ha a szociális állam körvonalai bontakoznak, ha mindenkinek hoz; az Isten megcsinálja. Most csak a mocskos fickókat látni öklükkel, s hallani, s szagolni mosdatlan szájuk köpködését; de azért az új világ közeledtét érezzük, a sorsa fordulását, a világtörténelmi dráma új felvonását!"24

Amikor aztán megtörtént a kommün bukása, akkor a következőt írta: „Ne akarjon itt letörni senki munkást, senki szegényt és proletárt! Én vagyok az első, s remélem, velem tart e részben minden a kor szükségletit $s$ a haladás irányát meglátó ember, aki minden reakciót, mely elnyomást, megtorlást, jogfosztást jelent, elítélek és a pokol fenekére, ahová való kívánok. Ellenkezőleg, azt hiszem és vallom, hogy [...] ha égő, s vágyó szemmel tartunk szemlét a magyarság jövőjének valamit ígérő tényezői fölött, akkor ezeket elsősorban a munkásrétegekben, az ipari munkás, a földmüves osztályokban reméljük föltalálhatni. Uralkodó osztályokból nem kérünk, azoknak végük van, legyen is, de vezető osztályokat ezentúl is tisztelünk és igénylünk." ${ }^{25}$

Mindezek után szeretnék visszatérni a modernizmus vádjára, s Prohászka akadémiai székfoglalójára: „Az intellektualizmus túlhajtásai”-ra. Tulajdonképpen megtévesztő a cím, mert ő nem az intellektualizmusról, hanem a racionalizmusról beszélt, és közben így is használta a szót az írásaiban. Eredeti kézirata jóval bővebb, mint a kinyomtatott szöveg, pontosan megjelöli a forrásait, így Edouard Le Roy Dogme et critique című könyvét is. Edouard Le Roy közvetítette számára Bergson és Blondel gondolatait is. Prohászka nem vallotta a modernizmus elveit, de rokon-

\footnotetext{
${ }^{23}$ Uo. 224-225.

${ }^{24}$ Prohászka Ottokár: Naplójegyzetek III., Székesfehérvár, Agapé, 1997, 31-32.

${ }^{25}$ Sík Sándor: Gárdonyi, Ady, Prohászka, Budapest, Pallas, 1928, 343.
} 
szenvezett Le Roy, Bergson és Blondel bizonyos nézeteivel, főleg az intuíció és a cselekvés döntő szerepére vonatkozó ismeretelméleti meglátásaikkal.

Prohászka úttörő megfogalmazásaival kapcsolatban - melyekben évtizedekkel megelőzte korát - alkalmazni kell az alapelvet: „Ami a katolikus Egyházban hangzik el, azt katolikusan kell értelmezni." Összefoglalva elmondhatjuk: Prohászka nem modernista volt, hanem modern.

Rómában, az „ad limina” látogatáson felvetettem a Szenttéavatási Kongregáció bíboros prefektusa előtt Prohászka kanonizálásnak kérdését. Megemlítettem Felici bíborosnak, hogy ennek Prohászka indexre tétele már nem lehet az akadálya, hiszen egyrészt II. János Pál pápa a Germanicum jubileumán nagy dicsérettel emlegette nevét, másrészt maga II. János Pál pápa kezdeményezte a neves dominikánus biblikus, M. J. Lagrange OP boldoggá avatási eljárását, akit a modernista viták idején ugyancsak cenzúráztak.

Felici bíboros jegyezte meg humorosan: „Ha szent akar lenni, ne írjon sokat!” Majd 1999. február 18-án levélben megírta, hogy végignézve a kongregáció irattárát, ott hivatalosan a boldoggá avatási eljárást soha nem indították el.

Prohászka esetleges boldoggá avatásával kapcsolatban főleg két problémára szokták felhívni a figyelmet. Az egyiket már említettem Felici bíboros tréfás megjegyzése kapcsán: „Ha szent akar lenni, ne írjon sokat!” Prohászka sokat írt, és annak ismeretéhez-megítéléséhez teljesen otthon kell lenni a 19. század végének, 20. század elejének minden szellemi mozgásában, Európában és hazánkban is. Műveinek egyetlen világnyelvre való lefordítása sem problémamentes. Írásai egy részét naplójába írta, amelyben nyomon követhetjük gondolkodását, fejlődését, problémafelvetéseit. Ezek nagy részét nem is kiadásra szánta.

Indexre tételével összefüggésben egyre több irat kerül elö. Az világos, hogy modern - de nem modernista - nézetei, s föleg a társadalmi reformjai, sokakat megijesztettek. Így aztán elindult ellene a belső áskálódás. Írásaiban minden bizonnyal lehetett félreérthető teológiai megfogalmazásokat találni, főleg ha azokat a környezetükből kiragadva idézték. Sajnos, nem vették figyelembe a katolikus alapelvet: „Ami a katolikus Egyházban hangzik el, azt katolikusan kell értelmezni.” Ma már - hála Isten - az indexre tétel ténye nem akadálya a boldoggá avatásnak.

A másik probléma lenne Prohászka valós vagy vélt antiszemitizmusa. Ennek megközelítéséhez a tényekből kell kiindulni. Az első ilyen tény, hogy Prohászka püspök 1927-ben halt meg. Ekkor az antiszemitizmusnak a hitleri holokausztban tetőződő folyamatáról még nem lehetett tudni. Sok megjegyzését - főleg a nem nyilvánosságnak szánt naplójában - nyilván másként fogalmazta volna 1945 után. Írásait, megjegyzéseit is „szituálni” kell, vagyis el kell helyezni a kor publicisztikájában. $S$ ha valaki beleolvas a kortárs szocialista, kommunista vagy polgári radikális újságok egyházzal kapcsolatos cikkeibe, akkor megjegyzéseit még nagyon visszafogottnak fogja érzékelni. 
A túlhaladott feudális struktúrákat és a korabeli vadkapitalizmust elítélő Prohászka reakcióit segít megérteni, ha figyelembe vesszük, hogy mind a tőkés-kapitalista vonalon, mind a baloldali, radikális, szocdem irányzatokban jelentős volt a zsidók szerepe. Gergely Jenő írja: „A történelmi irodalom, beleértve az egykor magát marxistának vallót is, meggyőzően bizonyította a magyarországi, sőt a közép-kelet-európai polgári fejlődés jellemző vonásaként az igen dinamikus zsidó etnikum ebben játszott kiemelkedő, esetenként és helyenként meghatározó szerepet. Ennek elsorolása nélkül is kézenfekvő, hogy a bárhonnan jövő kapitalizmus-kritika szembetalálta magát ezzel a ténnyel.

A nem valláserkölcsű indíttatásúak ezt általában azzal hidalták át, merő materiális és ökonomikus argumentációval, hogy a tőke, a kapitalizmus nemcsak nemzetközi, hanem etikailag is indifferens, további sikeres vagy sikertelen müködése ezektöl független." ${ }^{6}$

Ha mindezekhez hozzávesszük Prohászka személyes emlékeit a 19-es kommünről, annak vezetőiről, sok minden érthetőbbé válik írásaiból.

Ugyanakkor Prohászka nem azonosult azokkal a jobboldali radikális kapitalista kritikákkal, amelyek minden baj forrásának, mintegy cinkosuknak a hazai zsidóságot tették meg.

Gergely szerint: „A problémát némileg leegyszerüsítve úgy is fogalmazhatjuk: nem az a választóvonal, hogy ki volt istenhívő keresztény vagy istenhívő zsidó, hanem az, hogy ki helyezkedett a valláserkölcsöt elvető radikális liberális vagy szocialista platformra - ami részint együtt járt egyfajta nemzeti közömbösséggel is - és ki nem." ${ }^{27}$

Prohászka szerint van jó zsidó és rossz zsidó, ahogy van jó keresztény és rossz keresztény, van magyar hazafi, $s$ van, aki méltatlan erre a névre.

1920. június 30-án írta naplójába: „, Keresztény kurzus « kereszténység, keresztények nélkül! Ez a baj, hogy e hordónak nincs feneke; e pártnak nincs alap, szirt a lába alatt.” ${ }^{28}$ Gergely Jenő szerint: „,A fö cezúrák, a törésvonalak tehát az ő társadalomfelfogásában a társadalmi igazságosság és igazságtalanság, a hit és a nemhit, a hazafiság és a hazátlanság mezsgyéjén húzódnak."29

A forradalom után elfogadott ún. „numerus clausus” törvény, amelyet Prohászka is támogatott, egyértelmüen ellenkezik az emberi jogokkal és a jogállami normákkal. S ezt ki kell mondani. Mi, mai katolikusok nyugodtan kimondhatjuk, hogy a II. vatikáni zsinat Dignitatis humanae kezdetü nyilatkozata után, ha lehetö-

\footnotetext{
${ }^{26}$ Gergely Jenő: Prohászka Ottokár hitéleti működése, in Szabó Ferenc (szerk.): Prohászka ébresztése, Budapest, Távlatok, 1996, 200.

${ }^{27}$ Uo. 201,

${ }^{28}$ Prohászka: Naplójegyzetek III., i. m. 151.

${ }^{29}$ Gergely: Prohászka Ottokár közéleti működése, i. m. 201.
} 
ségünk lenne, akkor sem támogathatnánk semmiféle „numerus clausust”. De természetesen, semmi erkölcsi, jogi alapjuk nincs ennek támadására azoknak, akik 1989-ig támogatták és megvalósították a hívő keresztények, másként gondolkodók elleni „numerus clausust”, csak nem 6\%-ban, mint 1920-ban, hanem o\%-ban!

Gergely Jenő írja: „Prohászka - szerintünk - világosan látta, hogy a törvényjavaslat nem faji törvény, hanem társadalmi kérdésekben foglal állást. Ugyanis a »numerus clausus « elsősorban az erkölcsi feddhetetlenséget és a nemzethüség szempontjából való politikai megbízhatóságot állította döntő kritériumként a felvételt kérőkkel szemben. Függetlenül attól, hogy keresztény vagy zsidó volt-e az illető; csak ezután következett az a kitétel, hogy az izraelita vallású felveendők az országos arányszámuknak megfelelő 6\%-ot tehetnek ki. [...] A numerus clausus reakciós [...] aktus volt, [...] s ez az egyenlőség elvét sértette. Csupán azért foglalkoztunk ennyit e kérdéssel, mert a törvényt - $\mathrm{s}$ a körül Prohászka személyét - nem tartjuk az 1938-tól induló zsidótörvények közvetlen elözményének, netán az első zsidótörvénynek." ${ }^{30}$

Egyik utolsó írásában, melynek címe: „Zsidó testvéreimhez”, olyan gondolatokat fogalmaz meg Prohászka, amelyekkel szintén több mint 50 évvel megelőzte korát. Nemcsak a II. vatikáni Zsinat Nostra Aetate című nyilatkozatához közelít, hanem világosan kifejti a kereszténység zsidó eredetét, és „zsidó testvéreit” így szólítja meg: „Tartsátok azt, amit a próféták a jövőre nézve mondtak, s akkor nem fogjátok megvetni azt, amit Krisztus hozott. - Ne mondjátok, hogy nem veszitek el, mert ti zsidók vagyok. Krisztus is az volt, sokkal inkább, mint ti. Sőt, éppen mert zsidók vagytok, jövendölések alapján álltok, s nem szabad a régihez mereven ragaszkodnotok, hanem lélek szerint abba a jobb jövendőbe kell átlépnetek: Krisztusiakká kell lennetek! Nem a faj végett él az ember, nem azért, hogy a fajban, amennyiben az csak múlt, elmerüljön; hanem azért él, hogy benne, hitében s szeretetében az egész nem lelkisége magasabbra emelkedjék." ${ }^{31}$

Prohászka szavaival zárom előadásomat: „Ó Krisztus arc! Homályban állunk; a sötétség végtelen perspektívái nyílnak körülöttünk, mit nézzünk ki belőlük? [...] Ez éjben légy te a mi víziónk, dicsőséges és szép Krisztus! Halljuk a zürzavarnak éjében a küzdő, törtető géniuszok harci kiáltását, mely azt üvölti: keressük a jobbat! De mi azt feleljük: éljen a legjobb, s leborulunk előtted s imádunk téged!"32

Így fejezte be $A$ diadalmas világnézet címü könyvét az a Prohászka, akit Gárdonyi szép kifejezésével így nevezünk: „A napbaöltözött ember”.

\footnotetext{
${ }^{30}$ Gergely: Prohászka Ottokár - „A napbaöltözött ember”, i. m. 196-197.

${ }^{31}$ Schütz Antal: Prohászka Ottokár Összegyüjtött munkái, XXII, Budapest, Szent István Társulat, 1929, 346.

${ }^{32}$ Prohászka: A diadalmas világnézet, i. m. 141.
} 